\title{
EDITORIAL
}

\section{The newly founded Institute of Paediatric Virology and the 1918 flu outbreak: From mnemosyne to scientific truth}

\author{
DEMETRIOS A. SPANDIDOS \\ Laboratory of Clinical Virology, Medical School, University of Crete, 71003 Heraklion, Greece
}

Received January 12, 2020; Accepted April 24, 2020

DOI: $10.3892 /$ etm.2020.9417

'in truth all the data are in harmony'

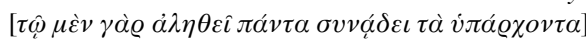

Aristotle

Truth is a value, which in medicine plays a significant role in the process of the acquisition of scientific knowledge (1). The Greek name for truth, 'alethea' $[\alpha \lambda \eta \dot{\eta} \theta \varepsilon \alpha]$, is derived from the ancient and modern Greek feminine noun ' $\alpha \lambda \eta \dot{\eta} \theta \varepsilon \iota$ ', meaning 'truth' and is as old as Homer; in Odyssea, Nestor promises Telemachus to tell him the whole truth about the death of

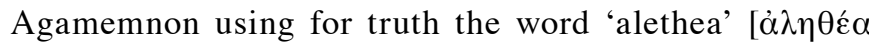
$\pi \alpha ́ v \tau$ ' $\alpha \gamma o \varrho \varepsilon v ́ \sigma \omega]$ (2). Seeking the truth requires personal effort to discover the meaning of the real and the objective, to understand all aspects of the reality and to achieve its collective acceptance. With this effort medical professionals try to understand human nature (3) and human needs and requirements and thus support humans by offering 'treatment' and 'cures' to the diseases that affect them. Opponents of this quest are lies and relativity. Lying is the expression of the untruth, which leads to the misunderstanding of reality. Relativity acknowledges the existence of many versions of the truth, which interpret reality differently and prevent the acquisition of true knowledge. For this reason the search for truth requires ethical virtue to reject lying and at the same time proper judgment that evaluates and questions the various versions of truth even if they come from experts or have already been widely accepted.

However, the process of the acquisition of the scientific truth also requires something that is often underestimated and neglected. Reversing the etymology of the word 'alethea', this comes from the privative 'alpha' and the word 'lethe' [ $\lambda \dot{\eta} \theta \eta]$, which means 'forgetfulness'. When something is 'alethes'

Correspondence to: Professor Demetrios A. Spandidos, Laboratory of Clinical Virology, Medical School, University of Crete, 71003 Heraklion, Greece

E-mail: spandidos@spandidos.gr

Key words: Institute of Paediatric Virology, paediatric virology, medical education, mnemosyne, inauguration speech
[' $\left.\alpha \lambda \eta \theta \dot{\varepsilon} \varsigma^{\prime}\right]$, this means that it cannot be forgotten, cannot remain hidden, cannot pass into oblivion; so true is something which is not latent, not concealed, but it is evident, tangible and real (4). The search for the truth has the meaning of the ascent, the manifestation of forgetting, the strength of revelation from obscurity and ignorance. This is how medical professionals can reveal the truth: to resist to oblivion of the past. The search for true knowledge apart from ethical virtue and proper judgment should be based on mnemosyne (5), which is also a word found in Homer; Hector asks his fellow not to forget to build a

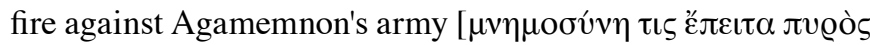

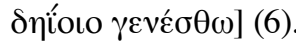

In the autumn of 1918, Yiannis, a 3-year-old boy, born in 1915 in a small fishing village at the south of the island of Euboea in Greece, lost both of his parents and his two older sisters due to the 1918 Spanish flu pandemic (7). His whole family was wiped out due to influenza, except for his two younger 6-month-old and 2-year-old cousins, Charikleia and Demetrios, who also lost both of their parents. According to the descriptions by the locals:

'...when the babies lost their parents, they were left in an old stone-made house, outside the village. Nobody from the village was visiting them, because they thought that their parents had died because of tuberculosis. Nobody, except for an old woman, who had no fear and every morning she was offering to them milk from her goat. This is how the babies managed to survive' (7).

Similar family cases attacked by influenza have been reported on the island of Euboea (8) as well as in the nearby islands of Skyros (8-10) and Andros (8); on the island of Skyros approximately one third of the whole island's population died of influenza in less than 30 days. The deaths were in family groups, while several cases of children, who managed to survive despite losing both their parents, have been reported (7).

All three children from the island of Euboea managed to survive. Yiannis moved to Kalamos in Attica working in the sea as a fisherman and at the age of 23 he created his own family in Karavos, the seaport of Aliveri, on the island of Euboea (Fig. 1). Charikleia and Dimitris spent their child- 


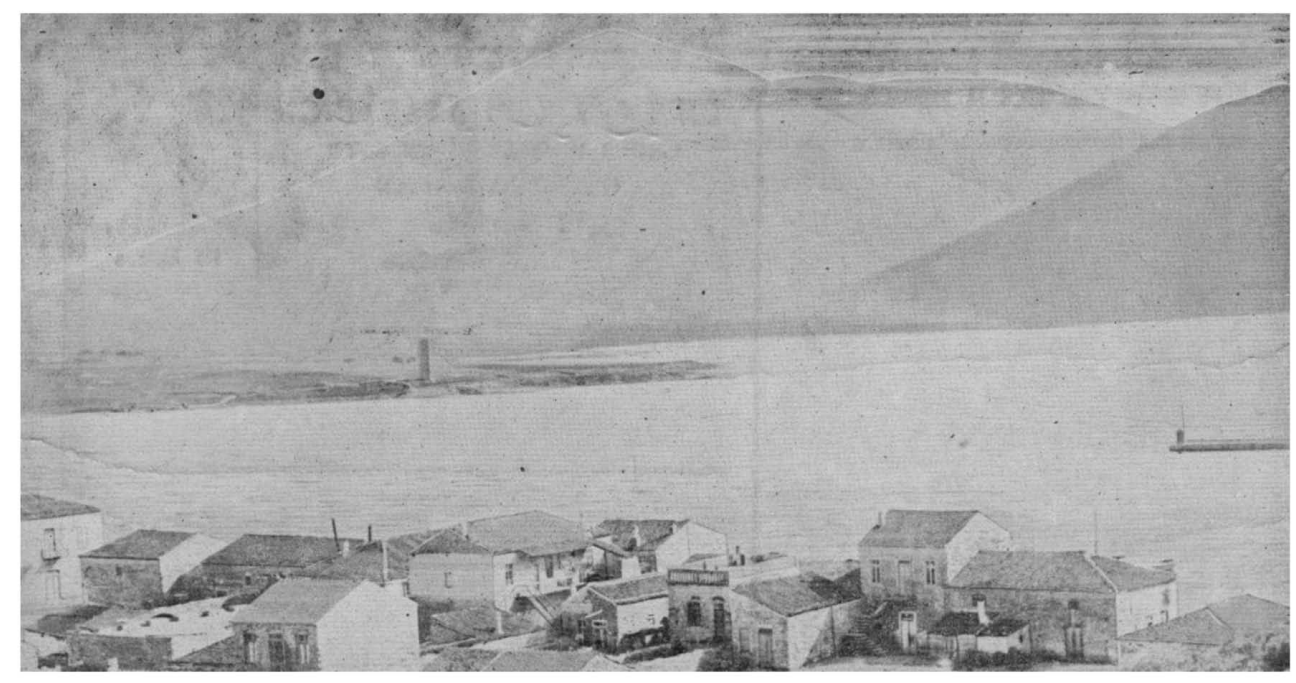

Figure 1. Karavos at the seaside of Aliveri on the island of Euboea at the beginning of last century.

hood in Cyme at the local orphanage and then they moved to Athens and to Chania on the island of Crete, respectively, creating their own families. During their whole lives, they

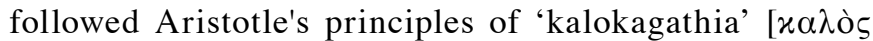
$x \alpha \dot{\gamma} \alpha \theta$ ó $\varsigma]$ as have been described in 'Ithika Eudimia' (11). Almost after 100 years, the foundation of the Institute of Paediatric Virology (IPV), which is based on the island of Euboea (12), is dedicated to the memory of the 3-year-old Yiannis, the 6-month-old Chariklia and the 2-year-old Demetrios; all three children managed to survive the 1918 'Spanish' flu outbreak. In case of a potential new pandemic with the same morbidity and mortality as the 1918 Spanish flu, how prepared are we really? If a similar epidemic treat appears, how differently modern society and medicine will act? How will our clinical practice be ready in real time to overcome current obstacles related to vaccination absence of several 'new' and 'old' emerging viral infections, the shortage of existing vaccines or hesitance, lack of effective antiviral agents and improper usage, inadequate supply or resistance to the existing ones, lack of medical and social health structures, limited relevant medical education (13)?

On the occasion of the 100-years anniversary from the outbreak of Spanish influenza in 1918, the newly founded IPV addresses a critical, currently underestimated necessity in modern medical education. This weakness of modern medicine towards neonatal and paediatric viral infections is asked to be further explored, evaluated and solved in the following years. The institute will try to implore the top leading research teams and centres of the world to re-consider and intensify their efforts in this direction. If the global medical and research community recognizes this priority, then the fundamental aim of the institute to 'add a tiny tile in future medicine' will have been achieved (14-16).

Nevertheless, it is not a coincidence that the newly founded IPV, which is based on the island of Euboea in Greece, rescues a historic moment of our past, trying to raise it to the modern scientific community. It saves from oblivion and reveals a historical fact, which is of particular value in the establishment of the institute and the achievement of its mission to highlight the new scientific field of neonatal and paediatric viral infec- tions $(17,18)$. Modern medical society should not forget the necessity for a new époque in the field of paediatric virology. The institute is an 'ark', where the salvage of the historical memory of the past marks the pursuit of this scientific truth with hope for the future.

\section{Acknowledgements}

This article is published in the context of the foundation of the Institute of Paediatric Virology (IPV; https:// paediatricvirology.org) based on the island of Euboea (Greece), under the auspices of the World Academy of Sciences (WAS) and the support of the Department of Clinical Virology of the University of Crete School of Medicine and the First Department of Paediatrics of the University of Athens School of Medicine. We would like to thank all the members of the IPV for their valuable comments and corrections.

\section{Funding}

No funding was received.

\section{Availability of data and materials}

Not applicable.

\section{Authors' contributions}

DAS contributed to the conception and design of this manuscript, wrote the original draft, edited and critically revised the manuscript, read and approved the final manuscript.

\section{Ethics approval and consent to participate}

Not applicable.

\section{Patient consent for publication}

Not applicable. 


\section{Competing interests}

DAS is Co-founder of the Institute of Paediatric Virology (IPV). DAS is the Editor-in-Chief for the journal, but had no personal involvement in the reviewing process, or any influence in terms of adjudicating on the final decision, for this article.

\section{References}

1. Aristotle: Nicomacheal Ethics A. In: Aristotle, Nicomatheal Ethics A-D, Apanta 7. Cactus, Athens, 1993 (In Greek).

2. Homer: Odyssea. Homer, Odyssea 1, Rhapsodies A, B, C, D. Cactus, Athens, 1992 (In Greek).

3. Hippocrates: On Ancient Medicine (Peri Arhaiis Iitrikis). In: Hippocrates, Apanta 1. Cactus, Athens, 1993 (In Greek).

4. Babiniotis G: Etymological Dictiobary of the Modern Greek Language - History of Words. Lexicology Centre, Athens, 2011 (In Greek).

5. Mammas IN: Clinical Virology research and medical education in Greece: An interview with Demetrios A. Spandidos, Professor of Clinical Virology at the University of Crete in Greece. Exp Ther Med 18: 3221-3225, 2019.

6. Homer: Ilias. In: Homer, Ilias 2, Rhapsodies E-TH. Cactus, Athens, 1992 (In Greek).

7. Mammas IN: The influenza in Port Buffalo in the island of Euboea: a family's reference. To Roptro 57: 62-66, 2019 (In Greek).

8. Mammas IN, Theodoridou M and Spandidos DA: The 'Spanish' flu outbreak at the islands of Skyros, Euboea and Andros 100 years ago. Int J Mol Med 42: S22, 2018.

9. Mammas IN, Theodoridou M and Spandidos DA: The 1918 Spanish flu outbreak that devastated a Greek island underlines past lessons that must never be forgotten. Acta Paediatr 107: 2034, 2018
10. Faltaits C: Influenza in Skyros, Annals. Vasileiou Editions, Athens, 1919 (In Greek).

11. Aristotle: Apanta 6. Kaktos Editions, Athens, 1993 (In Greek).

12. Mammas IN, Greenough A, Theodoridou M and Spandidos DA: The foundation of the Institute of Paediatric Virology on the island of Euboea, Greece (Review). Exp Ther Med (In Press).

13. Mammas IN and Spandidos DA: The future of medical education in neonatology, paediatrics and paediatric virology: An interview with Professor Alan Michael Weindling, Professor of Perinatal Medicine at the University of Liverpool. Exp Ther Med 16: 2805-2808, 2018.

14. Mammas IN and Spandidos DA: The subspecialty of Paediatric Virology: A 'mosaic tile' in future Paediatrics. Exp Ther Med 12: 539-540, 2016.

15. Mammas IN, Greenough A, Theodoridou M and Spandidos DA: Paediatric Virology: A new paediatric subspecialty? A proposal at the Workshop on Paediatric Virology, Athens, October 10, 2015. Exp Ther Med 11: 3-5, 2016.

16. Mammas IN, Greenough A, Theodoridou M, Kramvis A, Christaki I, Koutsaftiki C, Koutsaki M, Portaliou DM, Kostagianni G, Panagopoulou P, et al: Current views and advances on Paediatric Virology: An update for paediatric trainees. Exp Ther Med 11: 6-14, 2016.

17. Mammas IN, Greenough A, Theodoridou M and Spandidos DA: Educational pathways in Paediatric Virology: Pros and cons. Exp Ther Med 18: 3260-3262, 2019.

18. Drysdale SB, Bennett AM, Mammas IN and Greenough A: Training in paediatric virology in the UK: A brief overview (Review). Exp Ther Med (In Press).

(i) $($ This work is licensed under a Creative Commons Attribution-NonCommercial-NoDerivatives 4.0 International (CC BY-NC-ND 4.0) License. 